\title{
Advanced analysis methods applied to reconstructed and simulated paleoclimatic time series
}

\author{
C. Herrero ${ }^{(1,2)}$ and A. García Olivares ${ }^{(3)}$ \\ (1) Institut de Ciències del Mar (CSIC). Pg. Marítim de la Barceloneta, 37-49, 08003 Barcelona. \\ herrero@icm.csic.es \\ (2) Eurecat, Centre Tecnològic de Catalunya, Big data and Data Science Unit. Bilbao 72, Ed. A., 08005 Barcelona. \\ carmen.herrero@eurecat.org \\ (3) Institut de Ciències del Mar (CSIC). Pg. Marítim de la Barceloneta, 37-49, 08003 Barcelona. \\ agolivares@icm.csic.es
}

\begin{abstract}
The results of a simulated $\mathrm{CO}_{2}(C)$ and a global ice volume $(V$ time series, derived from a simple relaxation model of the glacial-interglacial cycles (García-Olivares and Herrero, 2013), have been analyzed using linear and non-linear techniques to evaluate the ability of the model on simulating the dynamics embedded on the climate system. On a first approximation, we have compared simulated time series with the corresponding paleoclimatic reconstructions, obtaining correlations of 0.88 between proxy-record $\delta^{18} \mathrm{O}$ (Lisiecki and Raymo, 2005) and simulated $V$, and 0.79 between reconstructed atmospheric $\mathrm{CO}_{2}$ concentration (Petit et al., 1999; Indermuhle et al., 2000; Monnin et al., 2001; Siegenthaler et al., 2005; Luthi et al., 2008) and simulated $C$. Spectral analysis using Fourier transform and continuous wavelet transform are useful tools to quantify the performance of a model for reproducing the dynamics embedded in reconstructed time series. The analysis shows that the model reproduces closely the dynamics embedded in the ice volume time series, but the coherence between the simulated and reconstructed $\mathrm{CO}_{2}$ is only sporadic, indicating that both time series do not follow the same dynamical behaviour, although in the deglacial periods the two carbon series become dynamically close. The analysis reinforces the hypothesis that some specific mechanisms included in the model are able to closely reproduce the glacial-interglacial oscillations and thus suggests which specific mechanisms should be more seriously investigated in the climate system. These techniques may be applied to other climatic time series to quantify the performance of a model simulating the dynamics of the climate system.
\end{abstract}

Key words: paleoclimate, relaxation model, glacial oscillations.

\section{Métodos de análisis avanzados aplicados a series paleoclimáticas reconstruidas y simuladas}

\section{RESUMEN}

Las series simuladas de $\mathrm{CO}_{2}(\mathrm{C})$ y de volumen de hielo global (V) derivadas de un modelo de relajación de ciclos glaciares-interglaciares (García-Olivares y Herrero, 2013) han sido analizadas usando técnicas lineales y no-lineales para evaluar la habilidad del modelos en simular la dinámica del sistema climático. En una primera aproximación, hemos comparado las series simuladas con su correspondiente serie experimental, obteniendo correlaciones de 0.88 entre el proxy $\delta^{18} \mathrm{O}$ (Lisiecki y Raymo, 2005) y la simulación V, y 0.79 entre la concentración de $\mathrm{CO}_{2}$ atmosférico (Petit et al., 1999; Indermuhle et al., 2000; Monnin et al., 2001; Siegenthaler et al., 2005; Luthi et al., 2008) y la correspondiente serie, C. El análisis espectral usando la transformada de Fourier y la transformada continua de wavelet resulta útil para cuantificar el rendimiento de un modelo reproduciendo la dinámica incluida dentro de una serie experimental. El análisis muestra que el modelo reproduce adecuadamente la dinámica de la serie de volumen de hielo, pero la coherencia entre la serie simulada y la experimental de $\mathrm{CO}_{2}$ es únicamente esporádica, indicando que ambas series no tienen el mismo comportamiento dinámico, pese a que en los periodos de desglaciación las dos series de carbono tienen un comportamiento muy similar. El análisis refuerza la hipótesis que ciertos mecanismos específicos incluidos en el modelo son capaces de reproducir adecuadamente las oscilaciones glaciares-interglaciares. Estas técnicas pueden aplicarse a otras series climáticas para cuantificar el rendimiento de un modelo simulando la dinámica interna del sistema climático.

Palabras clave: paleoclima, modelo de relajación, oscilaciones glaciales. 
C. Herrero and A. García Olivares, 2018. Advanced analysis methods applied to... Boletín Geológico y Minero, 129 (3): $509-524$

VERSIÓN ABREVIADA EN CASTELLANO

\section{Introducción}

La evolución del clima del Pleistoceno tardío está aparentemente relacionada con el forzamiento de Milankovitch (Hays et al., 1976; Paillard, 2010), donde las oscilaciones glaciares e interglaciares muestran un ciclo característico de $100 \mathrm{ka}$, tal y como se observa en los registros de hielo y sedimento (Petit et al., 1999; Indermuhle et al., 2000; Monnin et al., 2001; Siegenthaler et al., 2005; Luthi et al., 2008; Lisiecki y Raymo, 2005).

Varios modelos de relajación han sido desarrollados por García-Olivares y Herrero (2012, 2013), siguiendo la línea de Paillard y Parrenin (2004). Uno de esos modelos, $3 \tau$ de ahora en adelante, es capaz de reproducir los últimos ocho ciclos glaciales usando parametrizaciones de la estratificación profunda oceánica junto con tres variables acopladas: la concentración de $\mathrm{CO}_{2}$ atmosférico, el volumen de hielo global y la extensión de la capa de hielo Antártica.

\section{Modelo}

El modelo $3 \tau$ (García-Olivares and Herrero, 2013) predice el cambio de esas tres variables acopladas, $V, A$ y $C$, las cuales tienden exponencialmente a los estados de referencia $V_{r}, A_{r}$ y $C_{r}$ con tiempos característicos $\tau_{v,} \tau_{A} y$ $\tau_{c}$, respectivamente (Tabla 1). La Figura 1 muestra las series experimentales y simuladas.

La correlación puede usarse para cuantificar la varianza observada máxima, dándonos una idea de lo similares que son las series experimentales y simuladas entre ellas. La correlación obtenida es de 0.88 entre el proxy $\delta^{18} \mathrm{O}$ (Lisiecki y Raymo, 2005) y la serie $\mathrm{V}$, y de 0.79 entre la concentración experimental de $\mathrm{CO}_{2}$ (Petit et al. 1999; Indermuhle et al. 2000; Monnin et al. 2001; Siegenthaler et al. 2005; Luthi et al. 2008) y la serie C.

El mejor ajuste del modelo $3 \tau$ ha sido posteriormente validado con la serie de nivel del mar de Bintanja et al. (2005), la cual corrige posibles efectos de temperatura sobre la serie de $\delta^{18} \mathrm{O}$. La correlación aumenta hasta 0.90 , sugiriendo que la calibración realizada con los datos no corregidos ha producido un resultado robusto.

\section{Análisis avanzado de series temporales}

La Transformada de Fourier se ha utilizado para hallar el análisis espectral de las series experimentales y simuladas (Figura 2). Puede observarse que el contenido en frecuencia es similar en todos los casos, mostrando claramente los ciclos de Milankovitch de 100 y 41-ka, y de forma menos evidente el de 23-ka.

La transformada wavelet, la transformada cross-wavelet, la coherencia wavelet y el análisis de cross-recurrence son herramientas útiles para obtener información dinámica de las series temporales, las cuales complementan a la correlación y al análisis espectral.

Los análisis wavelet de las Figuras 3 a la 6, muestran que la banda de 100-ka es la frecuencia dominante, seguida de la de 41-ka y la de 21-ka, confirmando los resultados hallados con el análisis espectral. Sin embargo, en el caso del $\mathrm{CO}_{2}$, la distribución de frecuencias bajas entre las series experimentales y simuladas no coincide, sugiriendo que los mecanismos de nuestro modelo simplifican demasiado los detalles de la respuesta climática a escalas muy cortas de tiempo. El modelo no captura periodicidades en el rango de tres a diez $\mathrm{ka}$, seguramente debido a que los tiempos de relajación son del orden de $10 \mathrm{ka}$, no incluyendo por tanto tiempos de respuesta por debajo de ese orden de magnitud.

La transformada cross-wavelet compleja de dos series temporales podemos interpretarla como la intensidad compartida en un período determinado (Grinsted et al., 2004). Las Figuras 7 y 8 muestran que la serie $\checkmark$ y el nivel del mar de Bintaja están en sincronía en la mayoría de rangos de frecuencia, especialmente en frecuencias largas, sin embargo en el caso del $\mathrm{CO}_{2}$ parece haber alguna diferencia de fase en los primeros cuatro ciclos (entre -800 y $-400 \mathrm{ka}$ ) para frecuencias largas y en los últimos ciclos (entre -400 y $0 \mathrm{ka}$ ) para frecuencias más cortas.

La coherencia wavelet se usa para localizar correlaciones en el espacio de frecuencias, es decir, momentos en que dos series oscilan con la misma frecuencia y diferencia de fase (Figuras 9 y 10). Las correlaciones de $V$ están mayoritariamente en fase, pese a que se pueden observar ciertas diferencias entre la serie del modelo y la experimental en la banda de los 41-ka cerca de -500 ka. El caso de C, muestra un comportamiento ligeramente distinto entre los primeros cuatro ciclos, donde el modelo tiene más problemas, y los cuatro últimos.

Los atractores del espacio de fases son útiles para cuantificar la capacidad de una serie modelizada en reproducir las propiedades dinámicas de una serie experimental. Las Figuras 11 y 12 muestran los atractores 
C. Herrero and A. García Olivares, 2018. Advanced analysis methods applied to... Boletín Geológico y Minero, 129 (3): $509-524$

de la serie $V$ y la experimental de nivel del mar. Ambos atractores no son idénticos pero presentan similitud en la forma y la amplitud del espacio de fases es cercana. Hay que tener en cuenta que el modelo está forzado externamente por la insolación y un forcing astronómico similar ha de actuar en el sistema climático. Dinámicamente, una de las tres dimensiones ha de estar en fase con el forzamiento externo, dejando únicamente dos grados de libertad.

El análisis de cross-recurrence (CRP) de dos series temporales representa la confluencia de estados en ambos sistema. Es una visualización de los momentos en que la trayectoria de un espacio de fases coincide con el espacio de fases del otro sistema (Marwan et al., 2007). Las Figuras 13 y 14 muestran los CRP de las series $V$ y nivel del mar, y $C$ y $\mathrm{CO}_{2}$ respectivamente. Las trayectorias de las series de volumen de hielo experimental y predichas coinciden a una distancia de 0.45 veces la desviación del espacio de fases en aproximadamente el $85 \%$ de los casos. Sin embargo, las trayectorias en el caso del carbono están peor simuladas, coincidiendo aproximadamente el $50 \%$ de las veces. Pese a todo, la dinámica de los intervalos donde el $\mathrm{CO}_{2}$ es máximo está en general bien simulada, de forma que parece suficiente para permitir que la dinámica de $V$ se ajuste adecuadamente a la dinámica experimental. Esto sugiere que la condición crítica del modelo para obtener un buen rendimiento es que la variable $C$ reproduzca correctamente la forma de las deglaciaciones.

\section{Conclusiones}

Técnicas avanzadas de análisis lineal y no-lineal se han utilizado para estudiar las similitudes entre una serie climática reconstruida y otra simulada. Se trata de herramientas útiles para cuantificar el rendimiento de un modelo en reproducir la dinámica oculta en las series experimentales.

La inspección visual de la Figura 1, así como las buenas correlaciones obtenidas, muestran que el modelo se ajusta adecuadamente a los datos observados y las frecuencias principales están bien reproducidas (Fig. 2). Los distintos análisis wavelet nos muestran los periodos en que el modelo reproduce mejor la dinámica observada, sugiriendo los procesos naturales que el modelo captura adecuadamente y, por supuesto también los que no captura. Los atractores son útiles para explorar si el modelo tiene una dinámica similar al sistema climático.

En el modelo, un conjunto relativamente sencillo de variables es capaz de generar una dinámica comparable a la de dos series climáticas experimentales, pese a que los mecanismos relacionados con la dinámica de la variable $C$ están peor representados que los mecanismos de la variable $V$, excepto en los momentos de desglaciación, cuando ambas variables representan adecuadamente el sistema climático. Ninguna de las variables es capaz de capturar escalas menores a $10 \mathrm{kyr}$, no pudiendo por tanto representar adecuadamente los eventos climáticos que actúan como disparadores de la desglaciación.

Estos métodos han sido aplicados a series temporales similares utilizando también otros modelos (García-Olivares y Herrero, 2013), mostrando resultados análogos. Este tipo de análisis refuerza la hipótesis que ciertos mecanismos específicos son los que gobiernan las oscilaciones glaciares-interglaciacles, y ofrece un marco para estudiarlos más en detalle. En nuestro caso, dos de estos mecanismos son la variación de la estratificación oceánica, $F$, y la capa de hielo Antártica, $A$.

Éstas técnicas pueden ser aplicadas a otras series temporales para cuantificar la capacidad de un modelo en simular la dinámica del sistema climático.

\section{Introduction}

The evolution of late Pleistocene climate is apparently related to the Milankovitch forcing (Hays et al., 1976; Paillard, 2010), where glacial-interglacial ice volume oscillations show a characteristic $100-k y r$ cycle, as recorded in Antarctic ice and deep-ocean sediment core records (Petit et al., 1999; Indermuhle et al., 2000; Monnin et al., 2001; Siegenthaler et al., 2005; Luthi et al., 2008; Lisiecki and Raymo, 2005).

García-Olivares and Herrero $(2012,2013)$ have developed some relaxation models following Paillard and Parrenin (2004), considering the $100-\mathrm{kyr}$ glacialinterglacial cycle as a relaxation oscillation between two different climatic modes, a slow glacial state and a fast deglaciation state, both forced by the insolation and both should include mechanisms that could explain the changes in the atmospheric $\mathrm{CO}_{2}$. The Antarctic ice sheet extent is proposed as a variable able to link climatic and $\mathrm{CO}_{2}$ glacial-interglacial changes. The key of the results is the identification of a strong non-linearity in the oceanic source of $\mathrm{CO}_{2}$ which is controlled by the vertical density structure of the deep ocean.

One of these models, hereafter $3 \tau$, is able to accurately reproduce the last eight glacial cycles using simple parametrizations of the dense water formation in the Southern Ocean and three coupled variables: 
atmospheric $\mathrm{CO}_{2}$ concentration, global ice volume and the extension of the Antarctic ice shelf. The simulations are encouraging as they correctly reproduce the pace and termination times of all the glacial cycles observed.

In next section the fundamental equations, dynamics and good performance of the model are presented. Afterwards, a non-linear analysis has been implemented to assess the dynamic behaviour of the $3 \tau$ model, using the Fourier transform, wavelet transform, embedded attractors and cross-recurrence plots. A discussion of the results, reinforcing the importance of the model's mechanisms on glacialinterglacial oscillations is presented in the last section.

\section{$3 \tau$ model}

The $3 \tau$ model (García-Olivares and Herrero, 2013) predicts the change of three dimensionless variables: global ice volume, $V$, atmospheric $\mathrm{CO}_{2}$ concentration, $C$, and the extent of the Antarctic ice sheet, $A$. $V$ is forced by the atmospheric $\mathrm{CO}_{2}$ and the northern Hemisphere summer insolation $\left(\mathrm{I}_{65}\right.$, as calculated by Berger (1978) where time zero corresponds to 1950); C is linked to global ice volume and deep-ocean inorganic carbon contribution, which depends as a Heaviside step function ( $H=1$ if $F<0 ; H=0$ otherwise) on ocean stratification, $F ; A$ is forced by sea level changes through $V$. The model equations are:

$$
\begin{gathered}
\frac{d V}{d t}=\frac{V_{r}-V}{\tau_{v}} \\
\frac{d A}{d t}=\frac{V-A}{\tau_{A}} \\
\frac{d C}{d t}=\frac{\left(C_{r}-C\right)}{\tau_{C}} \\
V_{r}=-x C-y I_{65}+z \\
C_{r}=-\beta V+\gamma H(-F)+\delta \\
F=a V-b A+d
\end{gathered}
$$

\begin{tabular}{|c|c|}
\hline Parameter & $3 \tau$ \\
\hline$\tau_{\mathrm{v}}$ & 16585 \\
\hline$\tau_{\mathrm{v} 2}$ & 3105.5 \\
\hline$\tau_{c}$ & 13505 \\
\hline$\tau_{\mathrm{A}}$ & 9004 \\
\hline$x$ & 0.905 \\
\hline$y$ & 0.489 \\
\hline$z$ & 0.946 \\
\hline$\beta$ & 0.336 \\
\hline$\gamma$ & 2.044 \\
\hline$\delta$ & 0.228 \\
\hline a & 0.54 \\
\hline$b$ & 1.205 \\
\hline$d$ & 0.483 \\
\hline $\mathrm{R}_{\mathrm{v}}$ & $0.88 / 0.90$ \\
\hline $\mathrm{R}_{\mathrm{c}}$ & 0.79 \\
\hline
\end{tabular}

Table 1. Parameter values used in $3 \tau$. $R_{v}$ and $R_{c}$ represent the correlation between proxy and modelled data for global ice volume, $V$, and atmospheric $\mathrm{CO}_{2}$ concentration, $C$, respectively. The two values displayed for $R_{v}$ correspond to the correlations with the $\delta^{18} \mathrm{O}$ (Lisiecki and Raymo, 2005) and ice volume (Bintanja et al., 2005) time series, respectively.

Tabla 1. Valores de los parámetros usados en $3 \tau . R_{v}$ y $R_{C}$ representan la correlación entre la reconstrucción paleoclimática y el modelo para el volumen de hielo global, $V$, y la concentración atmosférica de $\mathrm{CO}_{2}, C$, respectivamente. Los dos valores de $R_{v}$ corresponden a las correlación entre las series de $\delta^{18} \mathrm{O}$ (Lisiecki and Raymo, 2005) y nivel del mar (Bintanja et al., 2005) respectivamente.

The principal variables $V, A$ and $C$, tend exponentially to reference states $V_{r}, A_{r}$ and $C_{r}$ with characteristic times $\tau_{v}, \tau_{A}$ and $\tau_{c}$, respectively (Table 1 ). Reference volume $\left(\mathrm{V}_{\mathrm{r}}\right)$ decreases when $\mathrm{C}$ increases through constant $x$, and when $\mathrm{I}_{65}$ is high through $y$. The $\mathrm{CO}_{2}$ of reference $\left(C_{r}\right)$ decreases when $V$ is high through parameter $\beta$ and when the oceanic pulse of $\mathrm{CO}_{2}$ is on (through parameter $\gamma$ ). The $\beta$ parameter represents the feedback between ice volume $V$ and $\mathrm{CO}_{2}$. $F$ is the formation of deep water, which can also be understand as the deep ocean state (García-Olivares and Herrero, 2013). $F$ increases with ice volume $V$ through $a$, and decreases when the continental shelf areas are reduced (through $A$ and corresponding constant parameter $b$ ). Figure 1 shows the reconstructed and simulated time series.

Correlation coefficients may be used to quantify 
C. Herrero and A. García Olivares, 2018. Advanced analysis methods applied to... Boletín Geológico y Minero, 129 (3): $509-524$

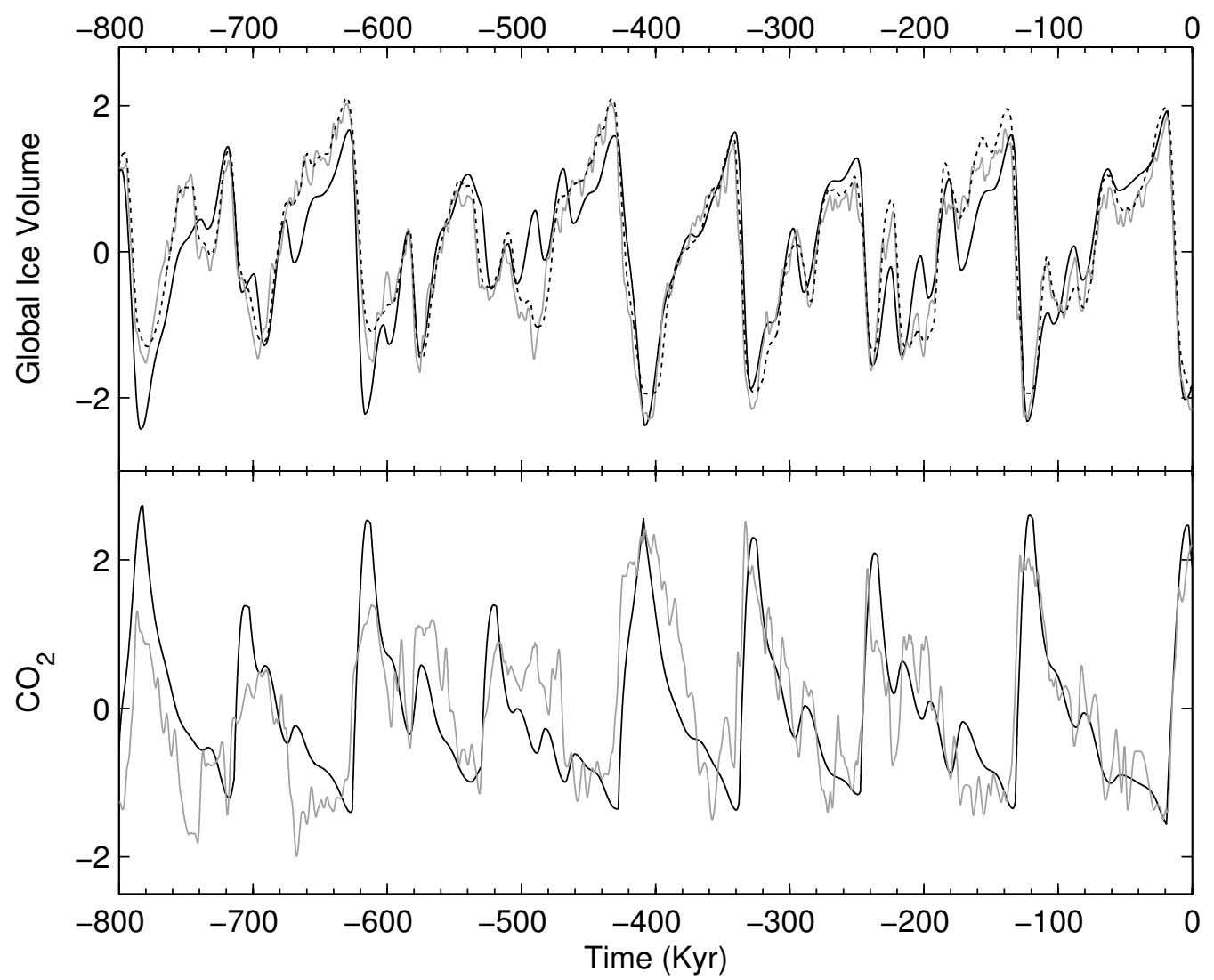

Figure 1. Top panel: normalized ice volume as predicted by $3 \tau$ model (black), proxy $\delta^{18} \mathrm{O}$ records from Lisiecki and Raymo (2005) (grey line) and relative sea level as obtained by Bintanja et al. (2005) (dashed line). Bottom panel: normalized $\mathrm{CO}_{2}$ as predicted by $3 \tau$ model (black) and proxy data (Petit et al. 1999; Indermuhle et al. 2000; Monnin et al. 2001; Siegenthaler et al. 2005; Luthi et al. 2008) (grey line).

Figura 1. Panel superior: volumen de hielo normalizado predicho por el modelo $3 \tau$ (línea negra), reconstrucción de $\delta^{18} \mathrm{O}$ de $L i s i e c k i$ and Raymo (2005) (línea gris) y nivel del mar relativo obtenido por Bintanja et al. (2005) (linea discontinua). Panel inferior: $\mathrm{CO}_{2}$ normalizado predicho por el modelo $3 \tau$ (línea negra) y la reconstrucción de $\mathrm{CO}_{2}$ (Petit et al. 1999; Indermuhle et al. 2000; Monnin et al. 2001; Siegenthaler et al. 2005; Luthi et al. 2008) (línea gris).

the maximum observational explained variance, giving us a first approximation of the similarity of simulated and proxy time series. The best-fit correlations were 0.88 (between proxy-record $\delta^{18} \mathrm{O}$ (Lisiecki and Raymo, 2005) and modelled $V$ and 0.79 (between the reconstructed atmospheric $\mathrm{CO}_{2}$ concentration (Petit et al. 1999; Indermuhle et al. 2000; Monnin et al. 2001; Siegenthaler et al. 2005; Luthi et al. 2008) and modelled $C$ ). The results are not very sensitive to a smoothing in the time series as the correlation between $V(C)$ and $\delta^{18} \mathrm{O}\left(\mathrm{CO}_{2}\right)$ series increases from $0.879(0.788)$, when using the raw data, to 0.882 (0.793), after smoothing the proxy data with a $2 \mathrm{kyr}$ moving average. Although the difference between the smoothed and raw data is not significant in correlation terms, the smoothed data were used for comparison between reconstructed and simulated time series.
The best-fit ice volume time series was then validated with the Bintanja sea level time series (Bintanja et al., 2005), which is supposed to remove the temperature effect from the $\delta^{18} \mathrm{O}$ time series. The correlation improved further to 0.90 , suggesting that our calibration with those uncorrected data has indeed produced a robust result.

\section{Advanced time-series analysis}

\section{Fourier Transform}

The Fourier analysis is useful to assess the spectral analysis of the reconstructed and simulated time series. The Matlab package FFT has been used for the calculations (Matlab is a trademark of The MathWorks). 
Spectral power of reconstructed and simulated time series were obtained with the Fast Fourier Transform and they are shown in Figure 2; on top the corresponding spectrum of simulated $V$ (black), smoothed $\delta^{18} \mathrm{O}$ (grey) and Bintanja sea level (dashed); at the bottom, simulated $C$ (black) and $\mathrm{CO}_{2}$ proxy (grey). Frequency content is comparable in simulated and reconstructed time series for both the $V$ and $C$ variables, showing the 100-kyr and the 41-kyr Milankovitch cycles clearly and, less evidently, the 23kyr band. However, in the $100-k y r$ band, $\delta^{18} \mathrm{O}$ has $10 \%$ more power content and $15 \%$ more power content in the $41-\mathrm{ky}$ band than the simulated $V$. The same is true when we use Bintanja's sea level, which has slightly more power content than the other two time series in all cases. In the 23-kyr band the power is relatively small in the simulated and observed time series. Considering $C$, the simulated and reconstructed power spectra are almost identical in the three primary frequencies, despite the fact that the correlations are worse than in the $V$ case.

\section{Wavelet Transform}

Wavelet transform, cross-wavelet transform and wavelet coherence are useful tools to obtain information from reconstructed and simulated time series, which is complementary to that obtained from the correlation coefficients and power spectrum. Figures 3 to 6 show the wavelet transform of the $V$, Bintanja sea level, $C$ and $\mathrm{CO}_{2}$ time series, respectively. Units in the colour bar are wavelet transform power, i.e. $\left|W_{i}\right|^{2}$, where $W_{i}$ is the wavelet transform or convolution between the Morlet wavelet function and the time series and " $\mathrm{i}$ " designates the position of datum number $i$. The thick black line above and below designates the $95 \%$ significance level against red noise and the thin black line designates the cone of influence where edge effects might distort the field. For the calculations, the Matlab software by Grinsted et al. (2004) (available at: http://www.pol.ac.uk/home/research/ waveletcoherence/) was used.

The 100-kyr band is the dominant frequency for all

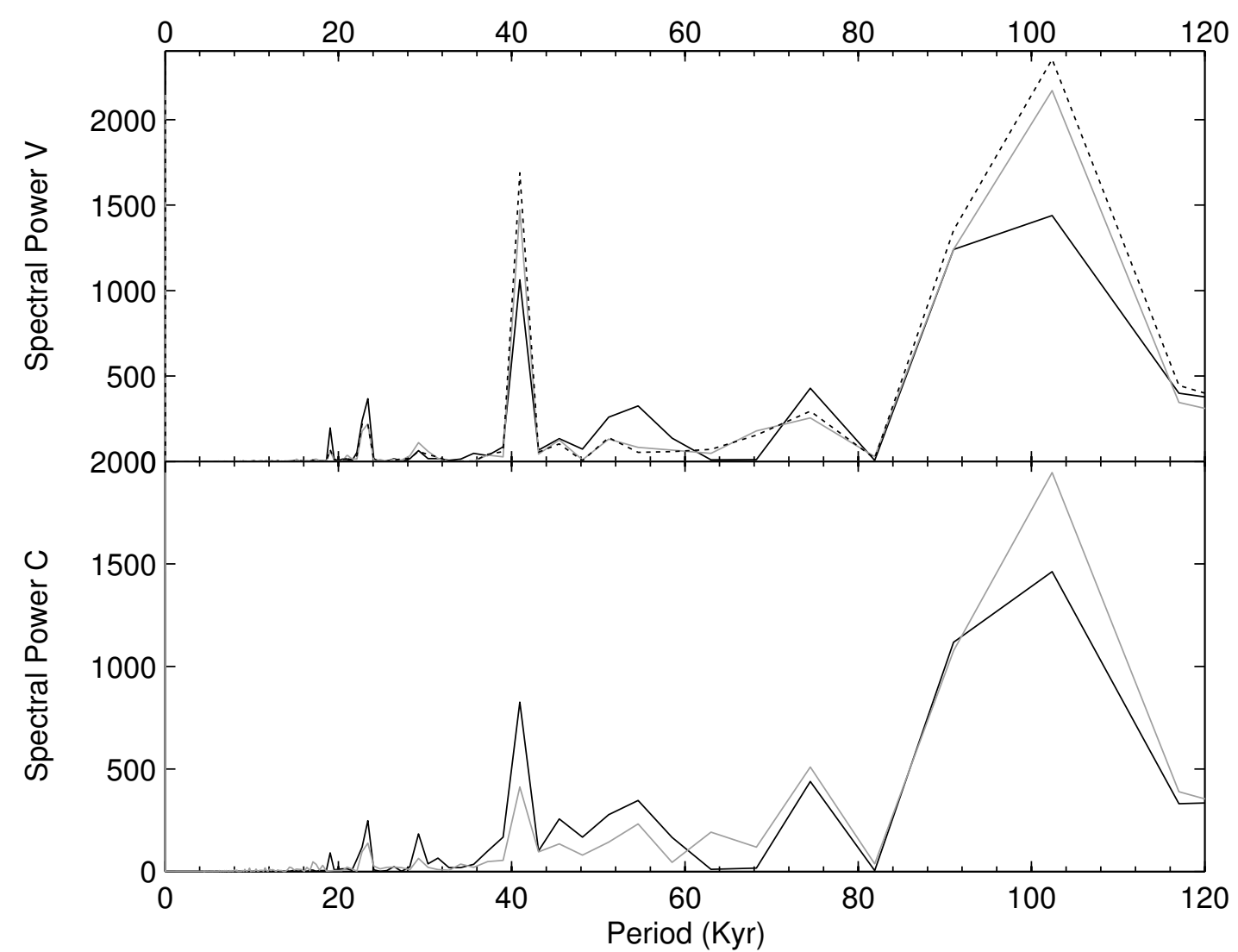

Figure 2. At top, the power spectrum of simulated $V$ (black), smoothed $\delta^{18} \mathrm{O}$ (grey) and Bintanja sea level (dashed); at the bottom, simulated $\mathrm{C}$ (black) and smoothed $\mathrm{CO}_{2}$ proxy (grey).

Figura 2. Arriba, el espectro de la curva simulada V (en negro), $\delta^{18} \mathrm{O}$ suavizado (gris) y el nivel del mar de Bintanja (discontinuo); abajo, el C simulado (negro) y el $\mathrm{CO}_{2}$ suavizado (gris). 



Figure 3. Wavelet diagram of the simulated $V$ time series.

Figura 3. Diagrama Wavelet de la serie temporal simulada $V$.

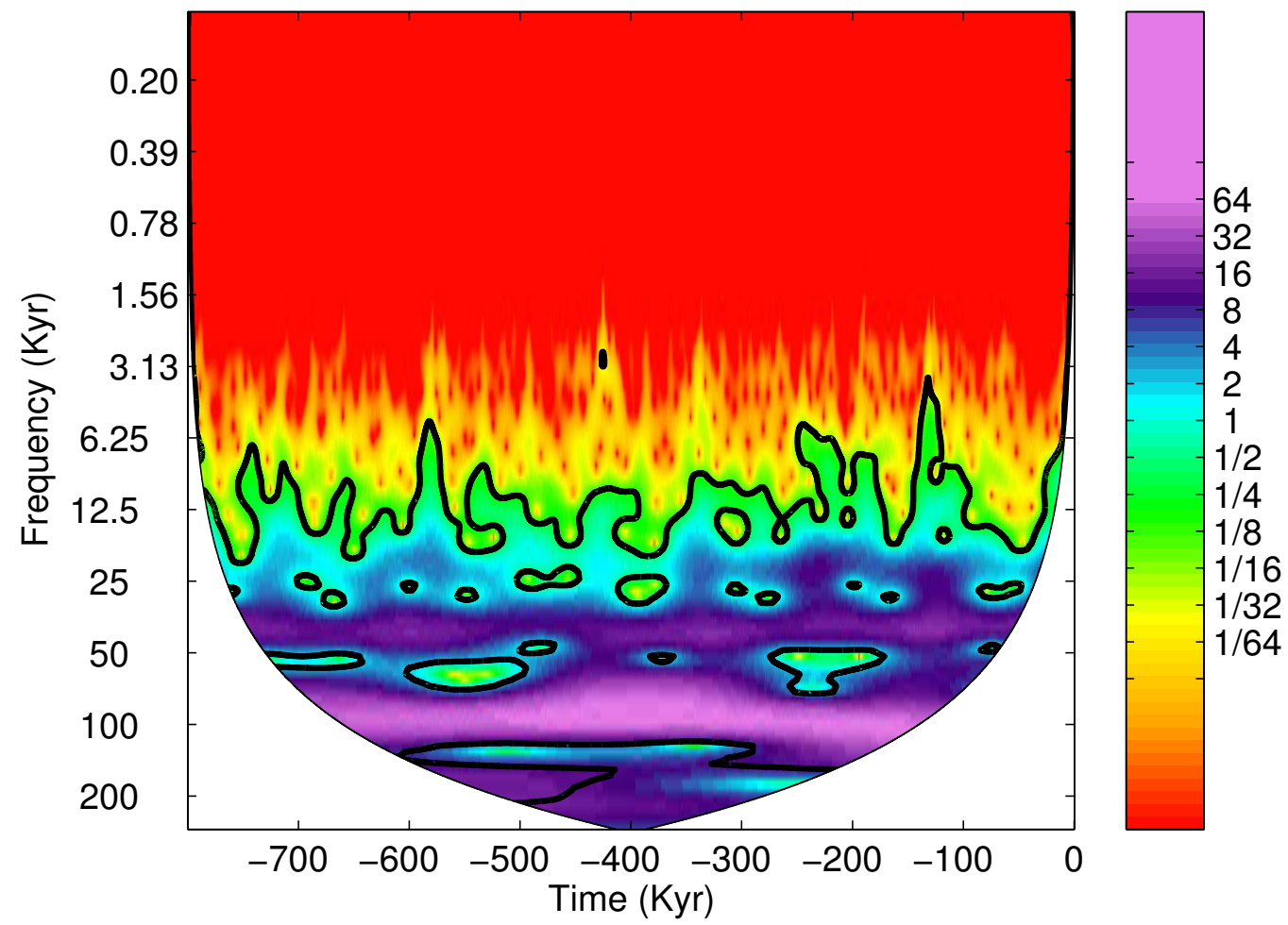

Figure 4. Wavelet diagram of Bintanja sea level time series.

Figura 4. Diagrama Wavelet de la curva de Bintanja de nivel del mar. 

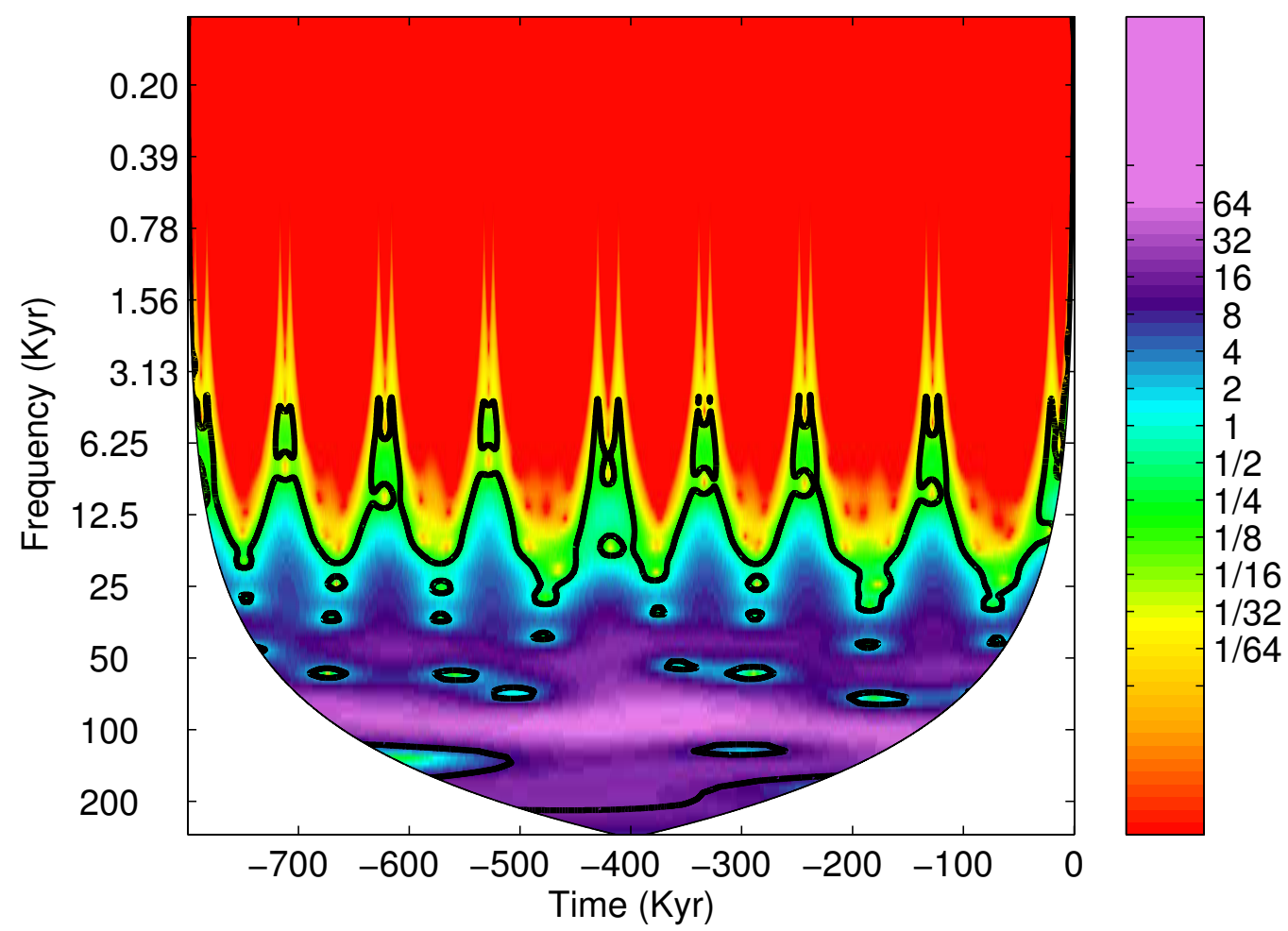

Figure 5. Wavelet diagram of the simulated $C$ time series.

Figura 5. Diagrama Wavelet de la serie temporal simulada $C$.

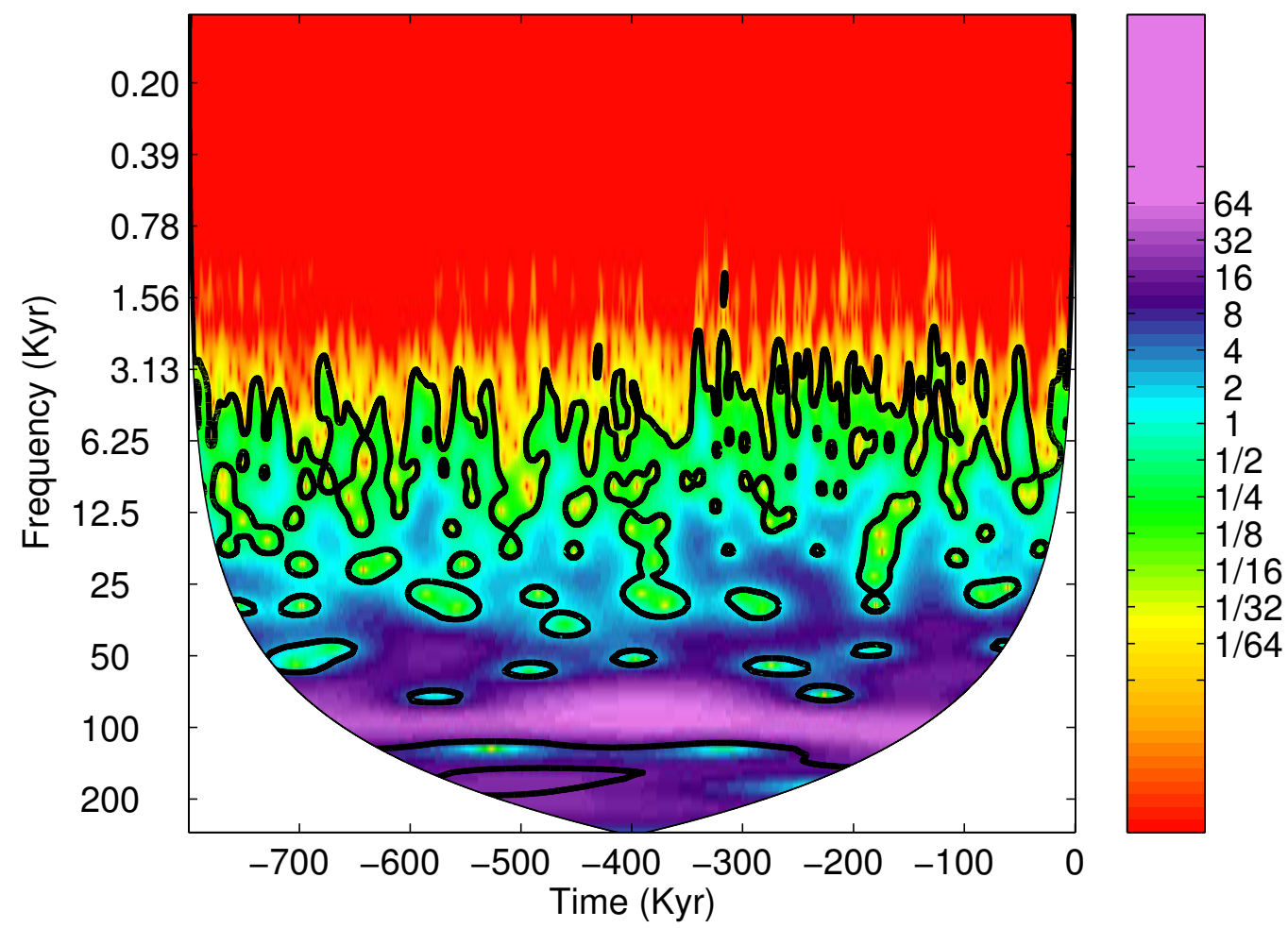

Figure 6. Wavelet diagram of smoothed $\mathrm{CO}_{2}$ proxy time series.

Figura 6. Diagrama Wavelet de la serie temporal suavizada del proxy de $\mathrm{CO}_{2}$. 
time series (shown in bright violet), followed by the 41-kyr band, obtaining a similarly distributed power in both bands for reconstructed and simulated series. The 21-kyr band is weakly present in all the time series. Thus, these results confirm those obtained from the Fourier analysis. Regarding $\mathrm{CO}_{2}$, the power distribution in the 100-kyr band is similar in the data and in the simulated time series, however, the distribution of power is different in the 41 and $23-k y r$ bands. This suggests that the mechanisms incorporated in our model are too simplistic to simulate the details of the climate response in these time scales. The proxy series also contain periodicities in the range 3-10 kyr, but our model is not able to generate any significant periodicity under $10 \mathrm{kyr}$. This is probably due to the relaxation constants used in the model $\left(\tau_{\mathrm{v}}, \tau_{\mathrm{A}}\right.$ and $\tau_{\mathrm{A}}$ in Table 1$)$, which are of the order of 10 kyr. The model does not include any time response with a period shorter than this order of magnitude.

The complex cross-wavelet transform of two time series (Figs. 7 and 8) can be interpreted as the shared power in a given periodicity band (absolute value) and the local relative phase between the two series in time frequency space (Grinsted et al., 2004). Lighter purple colour indicates greater shared power in that time and periodicity band, and the arrow angle indicates the phase between the reconstructed and simulated series.

As can be observed in Figure 7, the simulated $V$ and Bintanja's time series have a high common power in the 100 and 41-kyr frequencies at almost any time. Although the periodicities are in phase for the $100-k y r$ bands, in the $41-k y r$ band the modeled periodicity tends to lead the reconstructed one at some moments, with a phase of between 0 and $p / 4$. In the 41 and 23-kyr band the two periodicities tend to be in phase when the common power is high and out of phase when the shared power is low. Considering simulated $C$ and smoothed $\mathrm{CO}_{2}$ time series (Fig. 8), the 100-kyr band shows the largest shared power, especially after $-500 \mathrm{kyr}$, where the common features of the series are more evident. In the 41-kyr band the shared power is less evident, but shows a relative similarity especially between -600 and $-200 \mathrm{kyr}$, being in-phase initially but the modelled periodicity leads afterwards. Low shared power is observed in the 21kyr band, with an out-of-phase pattern in many intervals.

Another useful index is how coherent the cross wavelet transform is in time frequency space. In this

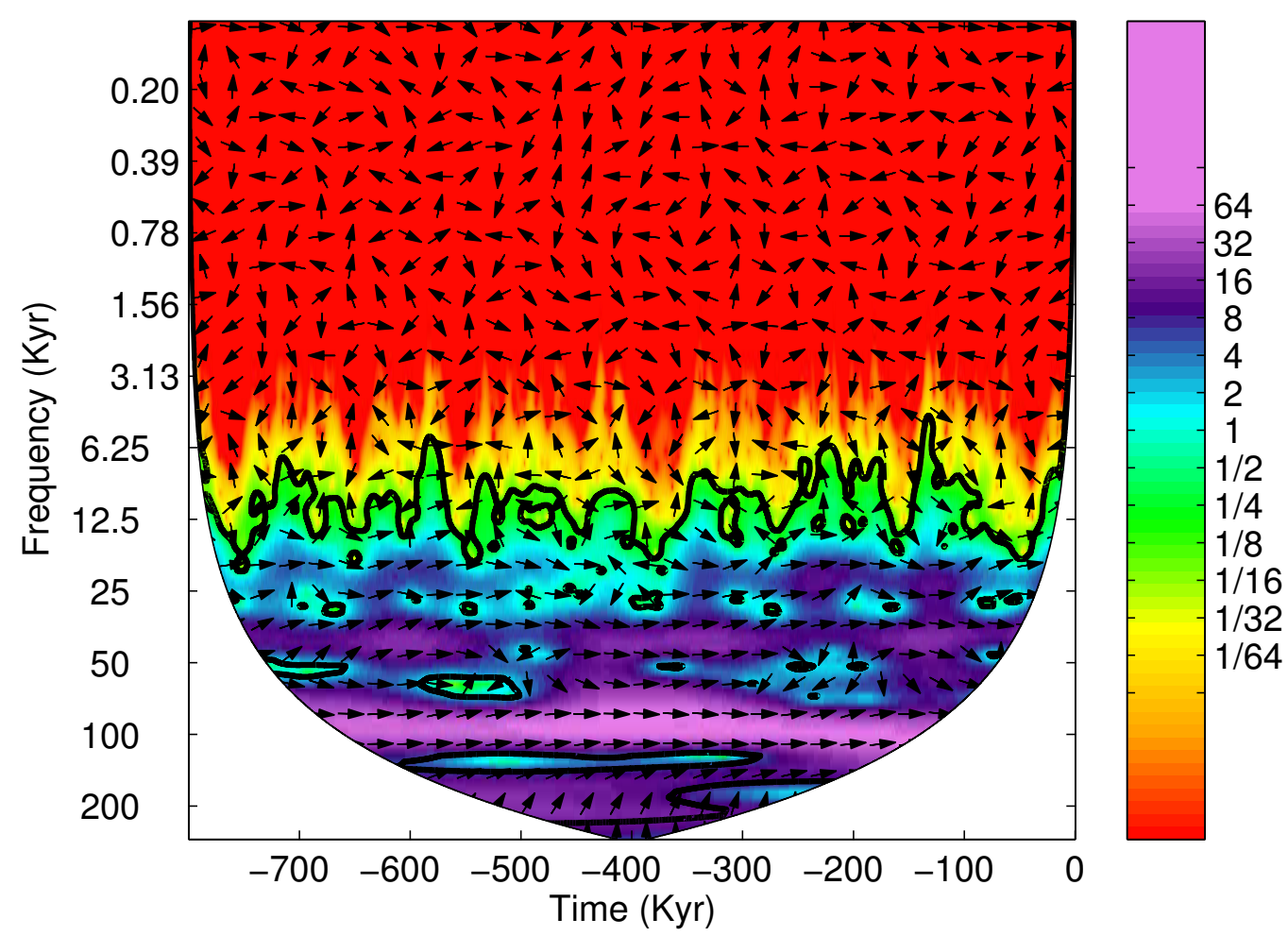

Figure 7. Cross-wavelet transform of the simulated $V$ time series and Bintanja's sea level time series. Figura 7. Transformada cross-wavelet de la curva $V$ y la serie de nivel del mar de Bintanja. 


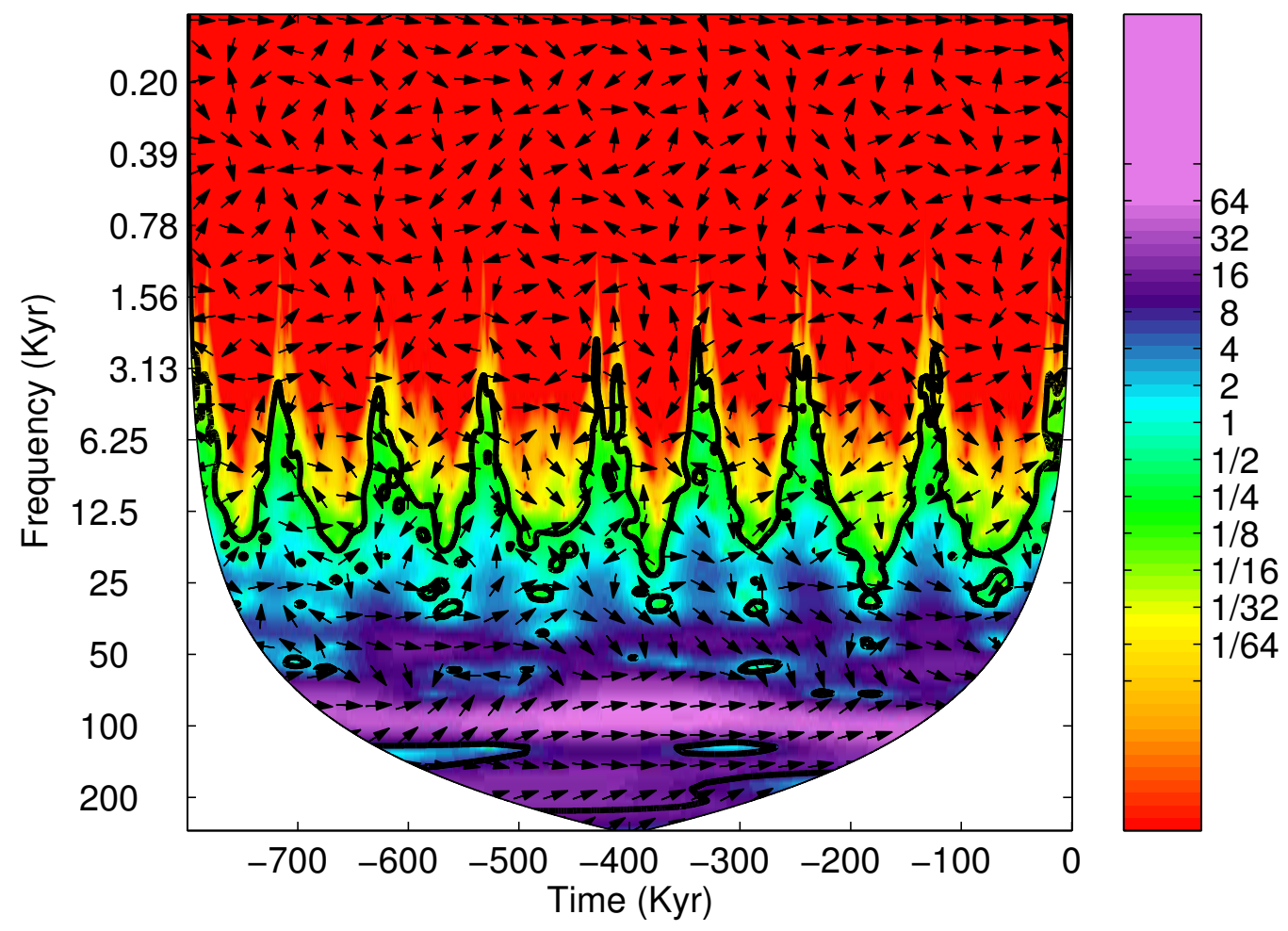

Figure 8. Cross-wavelet transform of the simulated $C$ time series and $\mathrm{CO}_{2}$ proxy time series.

Figura 8. Transformada cross-wavelet de la curva $\mathrm{C}$ y la serie de proxy de $\mathrm{CO}_{2}$.

regard, wavelet coherence of the two series can be interpreted as a localized correlation coefficient in time frequency space. This tool is useful to find locally phase-locked behaviour, that is, moments in which both series oscillate with the same frequency and a given phase difference. Figure 9 shows the wavelet coherence of the simulated $V$ time series and Bintanja's sea level time series and simulated $C$ time series and the proxy $\mathrm{CO}_{2}$ time series is shown in Figure 10. As can be observed, the $V$ correlations are always in phase, being larger than 0.9 , in all the 100 kyr band. In the 41-kyr band the correlation is also high, except close to $-500 \mathrm{kyr}$ and close to $-200 \mathrm{kyr}$, corresponding to intervals where the model is worse at matching the reconstructed series (see Fig. 1), and the model shows some problems to reproduce the phase of this band in the first half of the $V$ time series.

For $\mathrm{CO}_{2}$ and for 100-kyr frequency, the coherence is in phase and very strong after $-500 \mathrm{kyr}$ and weaker and out of phase before that time, coinciding with the first glacial cycles, which are more difficult to simulate for this model. The 41-kyr band shows a high coherence again after $-500 \mathrm{kyr}$, even though there are greater problems to reproduce the right phase of these oscillations, and there is practically non-existent coherence in the 21-kyr band.

\section{Phase space portraits}

Phase space portraits and embedding attractor techniques can also be useful for quantifying the performance of a simulated time series in matching the dynamical properties of a reconstructed time series. Time series of 16001 linearly interpolated equally spaced data were used to reconstruct the attractors. To avoid auto-correlated effects we used the method of mutual information (Roulston, 1999), which estimated an optimal time lag between data to be used of 1433 for $V$.

The first step is to see whether the attractor of the reconstructed time series is embedded in a phase space with the same dimensionality as the predicted time series. The dimensionality $D$ for the reconstructed time series is obtained with the method of false nearest neighbours (Marwan et al., 2007). The phase space dimension obtained was $D=4$, but the moving average of the reconstructed series with a 2-kyr window produced a smoothed time series with $D=3$. The dimensionality $D_{s}$ obtained for the simulated time series was $D_{s}=3$. Thus, the number of variables able to generate the smoothed reconstructed series is the same as that able to generate the simulated time series $\left(D=D_{s}=3\right)$. This suggests that generating the 




Figure 9. Wavelet coherence of the simulated $V$ time series and the Bintanja's sea level time series. Figura 9. Coherencia wavelet de la serie $V$ y el nivel del mar de Bintanja.



Figure 10. Wavelet coherence of simulated $C$ time series and the $\mathrm{CO}_{2}$ proxy time series.

Figura 10. Coherencia wavelet de serie temporal $\mathrm{C}$ y la serie de $\mathrm{CO}_{2}$. 
variability observed in the reconstructed time series under 10 kyr would require an additional independent variable in our model, provided that this variability does not derive from reconstructed noise.

Reconstructed attractors for the Bintanja's sea level and $V$ time series are displayed in Figures 11 and 12 , respectively. They are not identical but present a certain similarity in form, and the amplitude of the phase space is close. On the other hand, the models are forced externally by insolation, and a similar astronomical forcing is supposed to act on the climate system. In any externally forced dynamical system one of the dimensions has to be the phase of the external forcing, $j$, which allows the system to become autonomous through the equation $d j / d t=1$. Two additional variables, $v_{1}$ and $v_{2}$, remain available, so our three variables $V, C$ and $A$ must be considered as dependent on $v_{1}$ and $v_{2}: V=V\left(v_{1}, v_{2}\right), C=C\left(v_{1}, v_{2}\right)$ and $A=A\left(v_{1}, v_{2}\right)$.

\section{Cross Recurrence Plots}

The cross recurrence plot (CRP) of two time series represents the confluence of states of two systems. It is a visualization of a square matrix, in which the

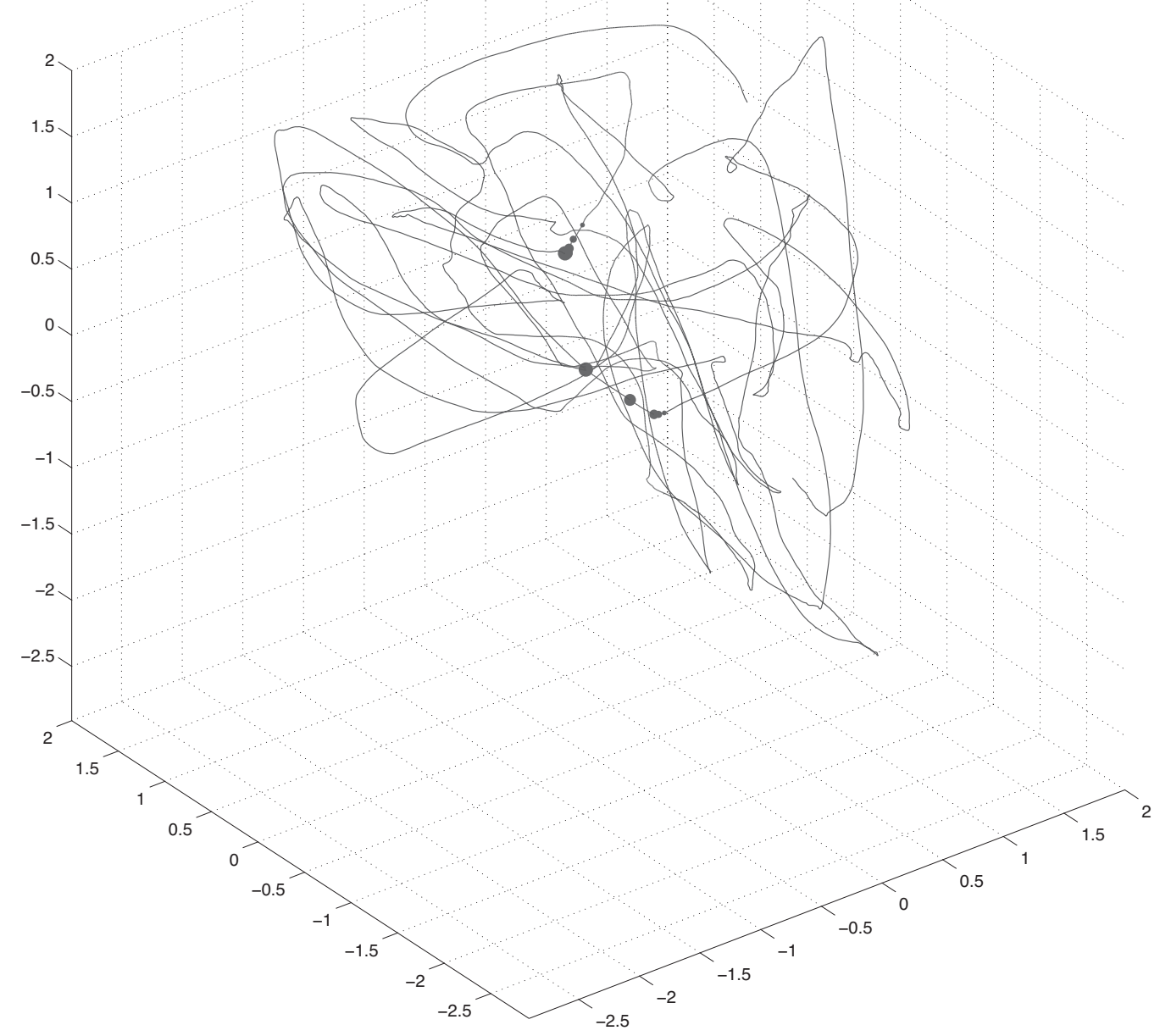

Figure 11. Embedded attractor of the Bintanja's sea level time series.

Figura 11. Atractor de la serie de Bintanja de nivel del mar. 


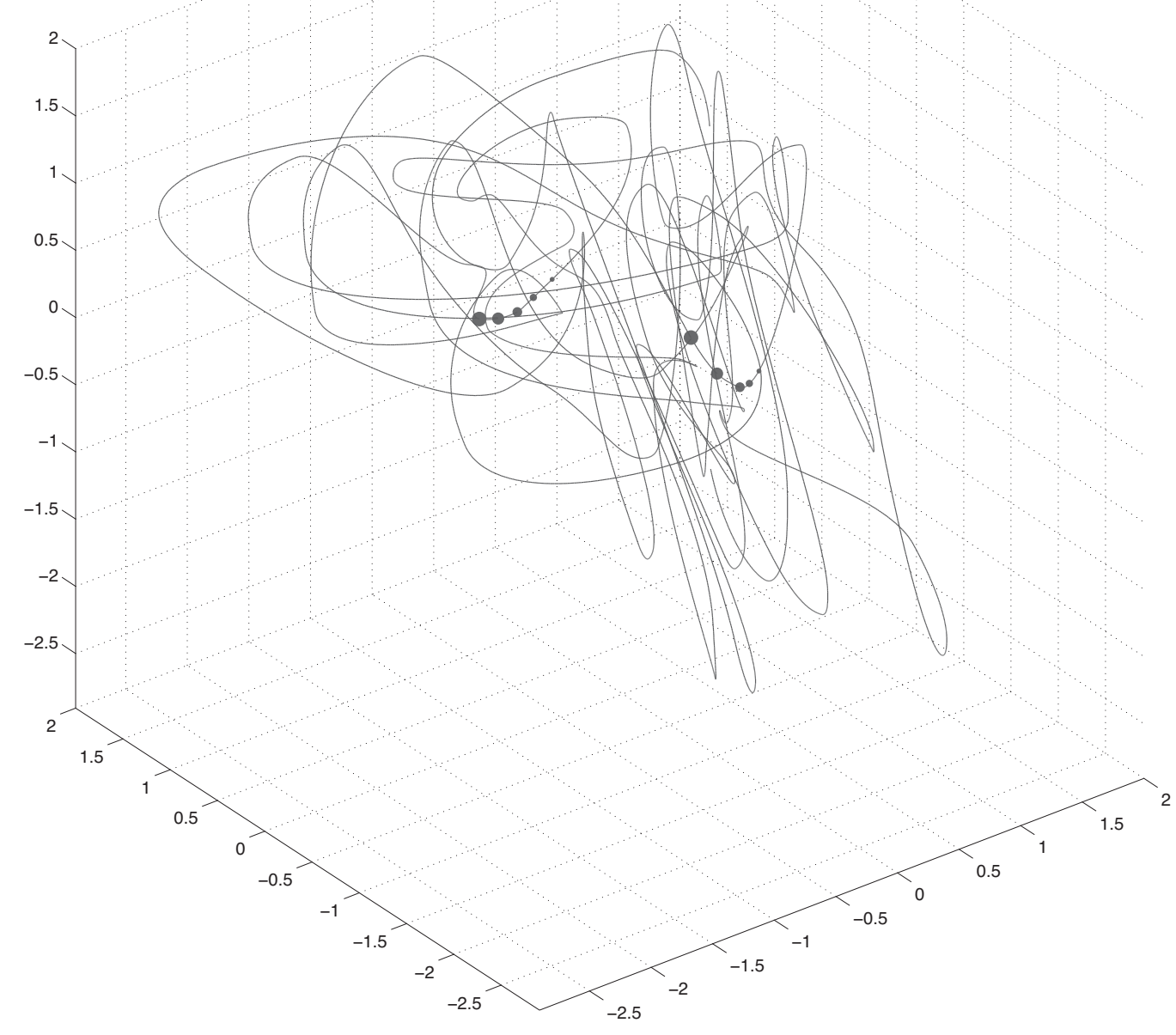

Figure 12. Embedded attractor of the simulated $V$ time series.

Figura 12. Atractor de la serie $V$.

matrix elements correspond to those times at which a state of a dynamical system recurs inside a given distance (columns and rows correspond then to a certain pair of times). The CRP reveals all the times when the phase space trajectory of the first system visits roughly the same area in the phase space where the phase space trajectory of the second system is (Marwan et al., 2007). The CRP obtained for the simulated $V$ time series and Bintanja's sea level time series is shown in Figure 13 and CRP for simulated $C$ time series and smoothed reconstructed $\mathrm{CO}_{2}$ time series is shown in Figure 14.

The Matlab tool by Marwan et al. (2007) was used for the calculations. In Figures 13 and 14 we can see the moments when the two series (reconstructed and simulated) coincide in the phase-space, being then, closer to one another at the same time (main diagonal) or with a given delay (secondary diagonals). We can see that the persistent intervals of good coincidence between $V$ and Bintanja's sea level series (Fig. 1) coincide with intense black patches in Figure 13, especially spots around 5000 and for $\mathrm{N}>8000$.

Many patterns occurring in the main diagonal appear deformed in lines and columns, indicating that the two series are roughly cyclical, and the way in which $V(t)$ coincides with Bintanja's sea level $(t)$ at 

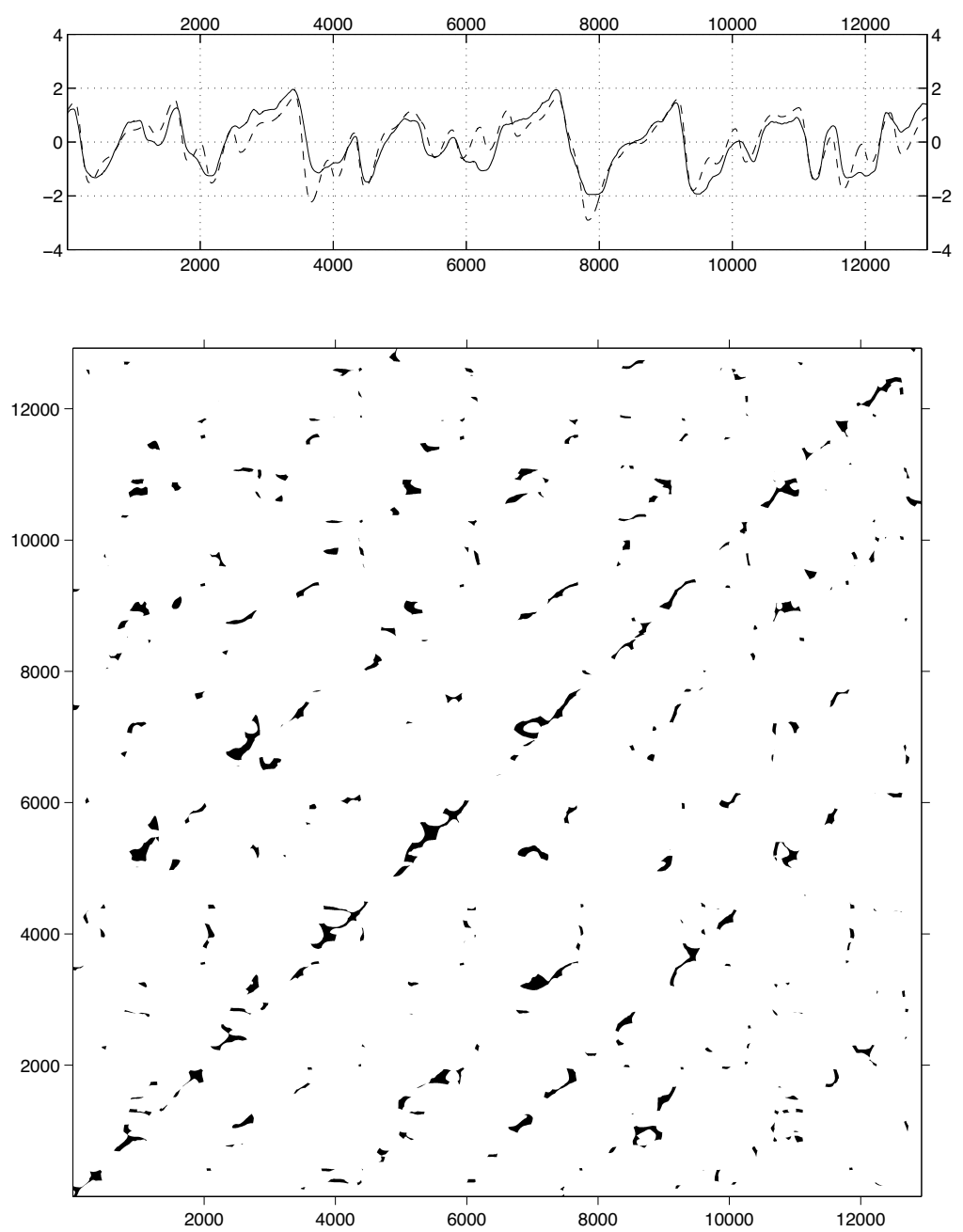

Figure 13. Cross-recurrence plots obtained for the simulated $V$ time series and Bintanja's sea level time series.

Figura 13. Cross-recurrence plot obtenido de la serie $V y$ el nivel del mar de Bintanja.

time $t$ shows similarity to the way in which $V(t)$ coincides with Bintanja's sea level $(t-T)$ where $T$ is the $100-$ kyr period.

Roughly $85 \%$ of the time the predicted and reconstructed $V$ trajectories are neighbours at a distance of 0.45 times the standard deviation of the phase space. The $C$ trajectories are much more poorly simulated, with the predicted and reconstructed trajectories being neighbours less than $50 \%$ of the time (Fig. 14). However, the dynamics in the intervals when the $\mathrm{CO}_{2}$ is maximum is normally well simulated, which seems to be sufficient to allow the $V$ dynamics to obtain a good similarity with the reconstructed dynamics. This suggests that the most crucial condition to obtain a good performance with this model is to get the variable $C$ to correctly reproduce the pace of the deglaciations.

\section{Discussion}

Some advanced techniques of linear and nonlinear data analysis such as the Fourier transform, wavelet transform, cross-wavelet transform, wavelet coherence, phase-space portraits and cross-recurrence plots have been used to analyze the similarities between reconstructed and simulated climatic time series. Those are useful tools to quantify the performance of a model at reproducing the dynamics embedded in reconstructed time series.

Other alternative techniques to study the model structure from the time series that it generates have been proposed. For instance, the study of possible "phase locking" between an external forcing and the internal periodicities of the model (Tziperman et al., 2006). However, this technique is not incompatible 
with the ones described here, since a model with the right mechanisms and non-linear locking should have higher correlations with the experimental time series, it should reproduce the pace of the experimental time series in the mean frequencies and it should generate time series with frequency composition and embedding dynamics similar to the reconstructed ones.

Visual inspection of Figure 1, as well as the good correlations obtained, show that the model offers a good agreement with the observed data and that the main periodicities are correctly reproduced, which is confirmed by the use of the Fourier periodogram. The wavelet analysis shows at what time periods the model better reproduces the observed periodicity and at what periods its performance is poorer, which may suggest the concurrence of natural processes that the model does not contemplate, thus playing a special role at those periods. Phase space portraits are useful to explore if the model is able to generate an attractor dynamically close to the one that is generating the reconstructed time series. In our model, the simple set of variables and mechanisms used seem able to generate a dynamics which is close to the one observed in the two reconstructed time series, even though the $C$ variable and the mechanisms related to it are less well simulated than the mechanisms that are related to the $V$ variable. On the other hand, the pace of orbital timescale is well simulated for $V$ and $C$, but in the suborbital timescales the phasing of $C$ is poorly matched in many periods that include the deglaciations (Fig. 9). In addition, the cross-recurrence analysis shows that the short-term coherence between simulated and reconstructed $\mathrm{CO}_{2}$ is only sporadic, indicating that both time series do not follow the same dynamical behaviour (Fig. 14). However, in the deglacial periods the two carbon series become dynamically close, which seems to be sufficient to get good correlations for the $V$ variable.


Figure 14. Cross-recurrence plots obtained for the simulated $C$ time series and smoothed $\mathrm{CO}_{2}$ proxy time series. Figura 14. Cross-recurrence plot obtenido de la serie $\mathrm{C}$ y el proxy de $\mathrm{CO}_{2}$. 
Finally, neither the simulated $C$ nor the $V$ match the observations on timescales 3-10 kyr, which are the timescales where the first events of the deglacial trigger take place. Mechanisms to simulate the climatic events that act as triggers of deglaciations are clearly lacking in this model.

\section{Conclusions}

These methods have been applied to a similar timeseries, the $\delta^{18} \mathrm{O}$ of Lisiecki and Raymo (2005) (GarcíaOlivares and Herrero, 2013) showing analogous results. This study confirms the previous conclusions and assesses the stability and robustness of the model. The analysis reinforces the hypothesis that some specific mechanisms are able to reproduce the main patterns of the glacial-interglacial oscillations and thus suggests that these specific mechanisms should be more seriously investigated. In our model, two of these mechanisms are the variation of the ocean stratification $F$ and of the Antarctic ice sheet, $A$, as a function of $V$. These techniques may be applied to other climatic time series to quantify the performance of a model simulating the dynamics of the climate system.

\section{Acknowlegments}

This study has been carried out in the framework of project TIC-MOC (CTM2011-28867), funded by the 2008-2011 Spanish R+D Plan. C. Herrero acknowledges a CSIC JAE-Predoc scholarship co-financed by the European Social Fund (FSE).

\section{References}

Berger, A. 1978. Long term variations of daily insolation and quaternary climatic changes. Journal of the Atmospheric Sciences, 35(12), 2362-2367.

Bintanja, R., R. S. van de Wal, and Oerlemans, J. 2005. Modeled atmospheric temperatures and global sea levels over the past million years. Nature, 437, $125-128$.

García-Olivares, A., and Herrero, C. 2012. Fitting the last pleistocene delta o-18 and $\mathrm{CO}_{2}$ time-series with simple box models. Scientia Marina, 76S1, 209-218.
García-Olivares, A., and Herrero, C. 2013. Simulation of glacial-interglacial cycles by simple relaxation models: consistency with observational results. Climate Dynamics, 41(5-6), 1307-1331.

Grinsted, A., Moore, J., and Jevrejeva, S. 2004. Application of the cross wavelet transform and wavelet coherence to geophysical time series. Nonlinear Processes in Geophysics, 11, 561-566.

Hays, J. D., Imbrie, J., and Shackleton, N. J. 1976. Variations in the earth's orbit: Pacemaker of the ice ages. Science, 194(4270), 1121-1132.

Indermuhle, A., Monnin, E., Stauffer, B., Stocker, N. J. and Wahlen, M. 2000. Atmospheric $\mathrm{CO}_{2}$ concentration from 60 to $20 \mathrm{kyr}$ BP from the Taylor Dome Ice Core, Antarctica. Geophysical Research Letters, 27(5), 735-738.

Lisiecki, L. E., and Raymo, M. E. 2005. A PliocenePleistocene stack of 57 globally distributed benthic delta O-18 records. Paleoceanography, 20(1), PA1003.

Luthi, D., Le Floch, M., Bereiter, B., Blunier, T., Barnola, J. M., Siegenthaler, U., Raynaud, D., Jouzel, J., Fischer, H., Kawamura, K., and Stocker, T. F. 2008. High-resolution carbon dioxide concentration record 650,000-800,000 years before present, Nature, 453(7193), 379-382.

Marwan, N., Romano, M. C., Thiel, M. and Kurths, J. 2007. Recurrence plots for the analysis of complex systems. Physics Reports, 438(5-6), 237-329.

Monnin, E., Indermuhle, A., Dallenbach, A., Fluckiger, J., Bernhard, S., Stocker, T. F., Raynaud, D., and Barnola, J. M. 2001. Atmospheric $\mathrm{CO}_{2}$ concentrations over the last glacial termination, Science. 291, 112-114.

Paillard, D. 2010. Climate and the orbital parameters of the Earth. Comptes Rendus Geoscience, 342(4-5), 273-285.

Paillard, D., and Parrenin, F. 2004. The Antarctic ice sheet and the triggering of deglaciations. Earth and Planetary Science Letters, 227(3-4), 263-271.

Petit, J. R., Jouzel, J., Raynaud, D., Barkov, N. I., Barnola, J. M., Basile, I., Bender, M., Chappellaz, J., Davis, M., Delaygue, G., Delmotte, M., Kotlyakov, V. M., Legrand, M., Lipenkov, V.Y., Lorius, C., Pépin, L., Ritz, C., Saltzman, E., and Stievenard, M., 1999. Climate and atmospheric history of the past 420000 years from the Vostok ice core Antarctica. Nature, 399, 429-436.

Roulston, M. S. 1999. Estimating the errors on measured entropy and mutual information, Physica D: Nonlinear Phenomena, 125, 285-294.

Siegenthaler, U., Stocker, T. F., Monnin, E., Lüthi, D., Schwander, J., Stauffer, B., Raynaud, D., Barnola, J. M., Fischer, H., Masson-Delmotte, V., and Jouzel, J. 2005. Stable carbon cycle-climate relationship during the Late Pleistocene. Science, 310, 1313-1317.

Tziperman, E., Raymo, M. E., Huybers, P., and Wunsch, C. 2006. Consequences of pacing the pleistocene $100 \mathrm{kyr}$ ice ages by nonlinear phase locking to milankovitch forcing. Paleoceanography, 21(4), PA4206.

Recibido: septiembre 2016

Revisado: diciembre 2016

Aceptado: enero 2017

Publicado: septiembre 2018 